\title{
Specific Financial Constraints of Innovative Companies: Theoretical Approach
}

\author{
Younes Ettahri, Abderrahim Laachach \\ Abdelmalek Essaadi University, Tangier, Morocco
}

\begin{abstract}
When a small and medium-sized enterprise (SME) decides to invest in an innovative project, it becomes attached to a high level of uncertainty (Hall \& Lerner, 2009) and it could meet some financial constraints (Kerr \& Nanda, 2014). This work is trying to apprehend the specific financial problems which SMEs, working on innovative projects, might face in a context characterized by a lack of liquidity, and it aims to improve the understanding of previous theoretical and empirical studies that dealt with the subject of financing these innovative companies. Moreover, it appears that it is important to ask the following question: Are there specific financial constraints to innovative SMEs? In order to answer the preceding question, this paper presents firstly the concept of innovation within companies. Secondly, it describes the specificities bound to the diverse financing approaches: in terms of risk, uncertainty, asymmetric information and profitability of an innovative project, while developing a theoretical approach concerning the possible constraints of financing the innovative companies.
\end{abstract}

Keywords: financing, innovative company, uncertainty, constraints, literature

\section{Introduction}

In a context of escaping a crisis characterized by a fierce international competition, the companies play a primordial role in creating richness and employments from diversified statuses within the small enterprise, to an innovative high tech. In parallel, to face the perpetual changes of their environment, the firms lead reflections on the innovation which is essential to insure their growth and their sustainable development. Hence, the investments dedicated to the Research and Development (R\&D) represent an important indicator of a dynamic intellect and are considered as a major factor in development and progress. It is relevant to take into account the economist J. Schumpeter (1934) who underlined in 1934 that innovation is a major driver of economic development. Additionally, the 10th edition of the Global Summit on Creativity and Innovation in Tampere (Finland - January 2014) and the extraordinary European Council in Lisbon (March 2000), as well as many different international summits and reports celebrated the high value of innovation in the economy of knowledge. As mentioned by Depret and Hamdouch (2008), financing is a primordial element for innovation and the source of support for the growth of the long-term activity. Often, the access to financing remains a major concern for innovative small and medium-sized enterprises (SMEs) rather than for the ones responsible with financial policies. In fact, the innovative SMEs often meet many difficulties as soon as it comes into question the satisfaction of their financial needs (Levratto, 1994; Pairault, 1993).

Younes Ettahri, Professor, GREFAM-ENCG of Tangier Morocco, Abdelmalek Essaadi University. Email: younesettahri@yahoo.fr.

Abderrahim Laachach, Ph.D. student, GREFAM-ENCG of Tangier Morocco, Abdelmalek Essaadi University. Email: laachach.abdo@gmail.com. 
It seems that it is instructive to ask the following question: Are there specific financial constraints to innovative SMEs? In order to answer the preceding question, this paper presents firstly, the concept of innovation within companies. Secondly, it analyzes the specificities connected to different financing approaches: in terms of risk, uncertainty, asymmetric information and profitability of an innovative project, while developing a theoretical approach concerning the possible constraints of financing the innovative companies.

\section{Innovation Within Companies}

Nowadays, innovation holds a fundamental place within companies, it is considered as a strategic factor for their growth (Freel \& Robson, 2004; Hoffman, Parejo, Bessant, \& Perren, 1998), and is the most important element in the elaboration of the strategy of an SME (O’Regan \& Ghobadian, 2005). In view of its importance, it is necessary to clarify the concept of corporate innovation, a concept that appears ambiguous and complex.

\section{The Concept of Innovation Within Companies}

A large literature exists in the area of innovation theory; therefore it turns out difficult to formulate a universal definition for this concept (Dosi, 1988). The innovation is a polysemous and polymorphic concept (Loilier \& Tellier, 1999). Most of the approaches confirm the diversity and the complexity of this concept, whereas this complex nature comes mainly from the automatism between innovation and technology which dominates in different functions on one hand and in the divergence of the classifications and typologies on the other hand (Dosi, 1988). The diversity of innovation may consist in the different visions addressed (David, 1996), among which we can cite:

(1) The implementation of the innovation as technical object, its nature, its technical and social realization (Delaunay, 1995; Sfez, 1973);

(2) Logic and organization of the products conception (David, 1988; Weil, 1996);

(3) The mechanisms of distribution (Schumpeter, 1934; Drazin \& Schoonhoven, 1996);

(4) The various processes and their impacts (Van de Ven, Polley, Garud, \& Venkataraman, 1989).

The reflections of the Austrian Joseph Schumpeter (1999) on innovation are pioneer in this domain. He defined in 1999 five forms of classical innovations (Villemeur, 2010): manufacturing of a new good, the introduction of a new method of production, an opening of a new outlet, the conquest of a new source of supply of raw materials of half manufactured goods, and a realization of a new organization. In fact, the authors distinguished between two levels of innovation: incremental innovation and radical innovation (Hamouti \& Robert, 2012). Incremental innovation assumes a linear cumulative change in a process or product, as "minor improvements or simple adjustments to current technology” (Dewar \& Dutton, 1986). On the other hand, notwithstanding, radical innovation requires non-linear paradigm changes which would represent significant departures from existing practices (Orlikowski \& Baroudi, 1991).

It is necessary to reference to the literature review on innovation performed by Garcia and Calantone (2002). In 2002, these authors classified innovation into three main categories (Denis, 2011):

(1) "New to": The industry, the world innovation, the scientific community, the market, the company and the customer...;

(2) "New what": New customer needs, technological innovation, new product features, new design, new processes, new services, new forms of competition, new customers and new consumption...; 
(3) “New uses”: Innovation in terms of skills, distribution, sales, improvements, new management skills, new experiences and new benefits.

Moreover, the Organization for Economic Cooperation and Development (OECD, 2005) proposes in its Oslo Manual (3rd edition, 2005) the following definition: "Innovation is the implementation of a new or significantly improved product (good or service), or process, a new marketing method, or a new organizational method in business practices, workplace organization or external relations”. These four types are considered as technological innovations. However, non-technological innovation includes two types of innovation: new methods integrated into the operational practices of the company relating to the organization of the workplace or to the external relations (these methods should not be already used by the company) and the implementation of a new concept or a new strategy which differ significantly from existing methods and have never been used before (Bernier, 2014).

The international reflections on the concept of innovation proposed by the OECD unify these diverse visions, thus the 3rd edition of Oslo Manual entitled Guidelines for Collecting and Interpreting Innovation Data is considered as an undeniable reference for any research in the field.

\section{Innovative Company: Definitions}

We have tried to present the most common definitions of "innovative company" from a wide literature (see Table 1).

Table 1

Various Definitions of “Innovative Company”

\begin{tabular}{|l|l|}
\hline & Definitions \\
\hline \multirow{5}{*}{$\begin{array}{l}\text { French Finance } \\
\text { Law }\end{array}$} & $\begin{array}{l}\text { According to the Article 44 sexies-0 A of general French tax code, a company is qualified to innovative start } \\
\text { realizing projects of research and development when, at the balance sheet date, it satisfies simultaneously the } \\
\text { following conditions: } \\
\text { (1) Respond to the qualification of either a small or medium company, that would employ less than } 250 \text { people; } \\
\text { (2) Realize a turnover lower than } 50 \text { million Euros or have a total of balance sheet lower than } 43 \text { million Euros; } \\
\text { (3) Being created less than eight years. A company can claim to have such status until its eighth birthday; } \\
\text { (4) It must not have been created as part of a merger, restructuring, extension of pre-existent activities or a } \\
\text { resumption of such activities; } \\
\text { (5) Realize research spending representing at least 15\% of the fiscally deductible loads engaged by the } \\
\text { company during the exercise; } \\
\text { (6) Having its capital held at least 50\% continuously. }\end{array}$ \\
\hline INSEE (France) & $\begin{array}{l}\text { According to the National Institute of Statistics and Economic Studies, innovative companies are those that } \\
\text { have introduced a significant change in at least one of the following four categories: products, processes, } \\
\text { organization, and marketing. }\end{array}$ \\
\hline OSLO & $\begin{array}{l}\text { According to the Oslo Manual (2nd edition - OECD), the innovative firm is “one that has implemented } \\
\text { technologically new or significantly technologically improved products or processes during the period under } \\
\text { review”, innovation has been implemented if it has been introduced on the market (product innovation) or used } \\
\text { within a production process (process innovation) (\$130). "It is one that has implemented technologically new or } \\
\text { significantly improved products or processes or combinations of products and processes during the period under } \\
\text { review” (\$199). }\end{array}$ \\
\hline
\end{tabular}

Note. Source: developed on the basis of OECD (2005), General French tax code (2015), and INSEE (retrieved from https://www.insee.fr/fr/accueil).

According to the literature, there are different designations of innovation, out of which we quote some, although this is not an exhaustive list: "knowledge-based companies” (Carpentier \& Suret, 2000), "high-tech firms” (Darby, Liu, \& Zucker, 2004), “companies-based research and development” (Aboody \& Lev, 2000), “new technology-based companies or technological innovations” (Deng, Lev, \& Narin, 1999), and “companies of new economy” (Bhojraj \& Lee, 2002). 
In Morocco, the OECD's work remains the source of inspiration of any reflection related to Moroccan innovative SMEs. We emphasize that the definition proposed by the OECD (OSLO) limits the innovation's impact to the production of market value added and reduces the count of innovative SMEs at a time $(t)$. On the other side, since the R\&D works take several years, with such a definition, high-tech SMEs would not be considered innovative over the period.

\section{Specific Features of an Innovative Project}

This section enumerates the traits of an innovative project in conjunction with the various financing approaches: in terms of risk, uncertainty, profitability and information, with the purpose of clarifying the problems of financing that may appear. We note that the logic of financing innovation includes associating the steps of the life cycle of a product. In fact, it is not difficult to discern the steps. On the contrary, the specific timing of each project is the heart of the reflection. For Lachmann (1993), the life cycle analysis is the only conceptual reference and a set of basic elements for the innovation financing. The main stages of the project life cycle can be divided into four phases (Barbe \& Stephany, 2003): the R\&D phase, the start-up phase, the growth phase, and the maturity phase. The following diagram (see Figure 1) attempts to synthesize the development stages of an innovative project.

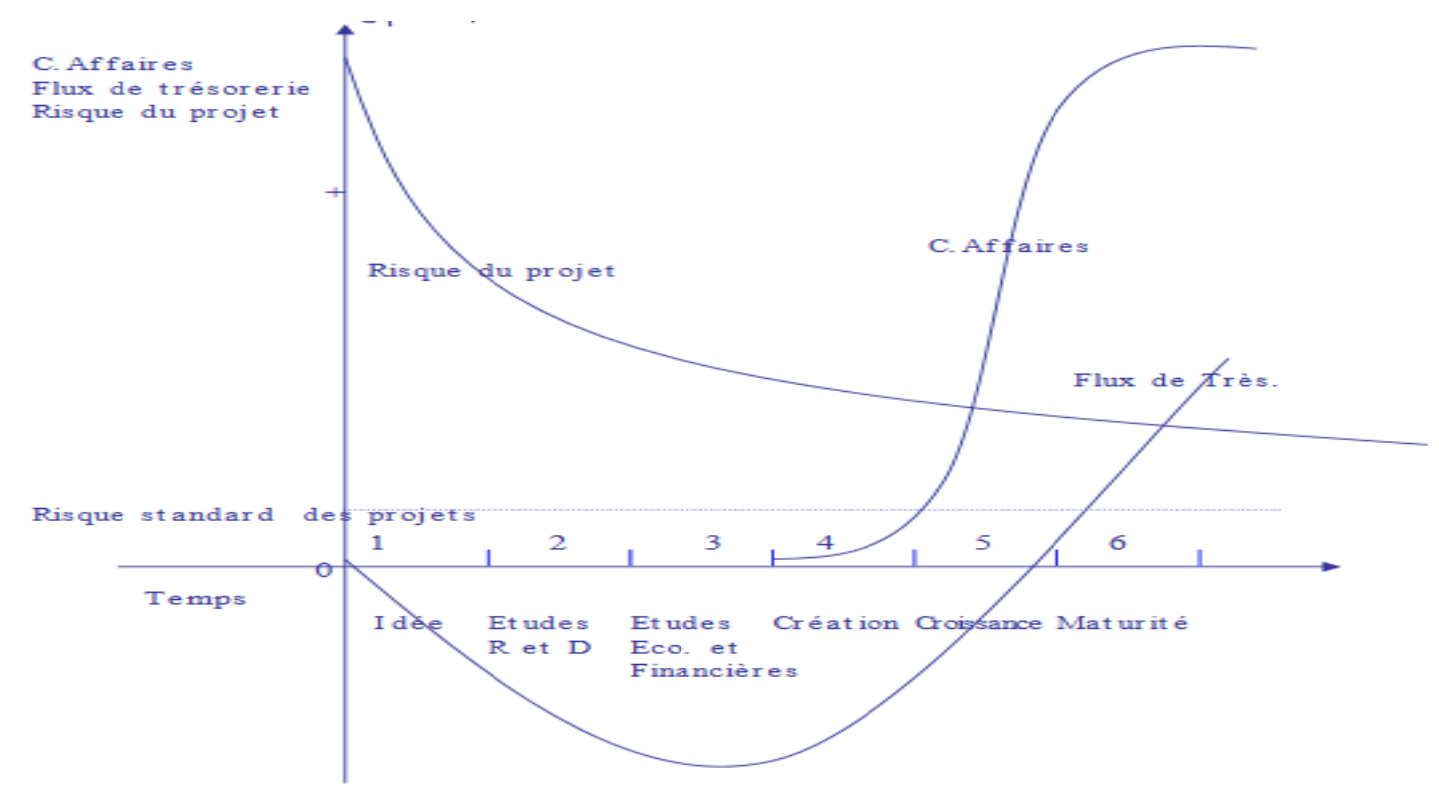

Figure 1. Stages of the project life cycle. Source: Barbe and Stephany (2003, p. 15).

\section{Innovation Process: Uncertainty and Risk}

Knight (1921, p. 233) distinguished between risk and uncertainty, when we talk about risk, the distribution of the result among a set of cases is known (either by a priori calculation or by the statistics based on observed frequencies), while this is not valid for the uncertainty due to the impossibility of combining the cases because the situation to be treated has a high degree of uniqueness. Depending on the economic monitoring report submitted to the Economic Development Observatory of Canada, written by St-Pierre and Beaudoin (1999), in October 1999, entitled Financing Innovation Within SMEs: A Recent Review of the Literature, the risk in SMEs is divided into three types: business risk, financial risk, and the risk related to the entrepreneur; for the business risk, it is 
associated to the company's production type, the technology used to the more or less strong dependence on a customer/product as well as towards a supplier, the risk of copying the product, to the proximity of competitors, and the company's market (St-Pierre \& Beaudoin, 1999). In fact, the risk is auxiliary to innovation and entrepreneurship; it accompanies the entrepreneur throughout the innovation process, the different time scales. Moreover, it is integrated, embedded in the normal process of innovation and accepted by its actors (Birraux \& Le Deaut, 2012).

In addition, the innovation process is by nature uncertain (Knight, 1921) and uncertainty is shared by all stakeholders in the early stages of the project life (Dubocage \& Rivaud-Danset, 2002). For Belze and Gauthier (2000), the uncertainty originates from "unobservability of objective criteria necessary for the evaluation of the project and also the difficulty of judging what is observable”. An innovative project uses a risky activity whose product is uncertain, especially at the research stage (Scherer, 1998). Boly, Renaud, Lopez, and Guidat (1998) distinguished between technical uncertainty and financial uncertainty in an innovative project. The first is related to the difficulty to ensure a technical solution for a large part of the development during the development of the process; very high sums of money can be spent for the construction of factories and acquisition of equipment while innovation is not yet ready. The second type reflects the difficulty of financial conducting of innovation into commercialization phase, while the risk remains important in the marketing phase and the success of the product or process does not necessarily take into account its intrinsic qualities (Alter, 1999).

\section{Asymmetry of Information and Specific Nature of Investments}

The commercial success of the innovation process, in which the level of information is sensitive, involves two important elements: secret and discretion, this is the reason why caution advices not to reveal information that can be useful to competitors (Bhattacharya \& Ritter, 1983; Levin, Klevorick, Nelson, Winter, Gilbert, \& Griliches, 1987) and not to reduce the asymmetry. It is therefore important to mention the situation of moral hazard, as a form of information asymmetry, which translates to "post-contractual opportunism resulting from the fact that some measures required or desired by a contract are not directly applicable” (Roberts \& Milgrom, 1997). Most times, neither the innovator nor the person in charge of finances can perceive the true potential of the project (Akerlof, 1970); the innovator can always be more informed about the project than the person in charge of finances (adverse selection). It is almost impossible to measure precisely the contributions in the process of innovation (Holmström, 1989). Also, the quality of the signal sent to the investors in an investment that is part of an innovative project is low, creating difficulties during distinction of the "good" projects from others. Note that the companies which are engaged in innovation have a high percentage of intangible assets, where knowledge is associated with the human capital (employees of the company), this key resource will be lost if the employees leave or are dismissed (Hall \& Lerner, 2009), resulting in additional costs of important adjustment related to expenditures of R\&D (Hall, Griliches, \& Hausman, 1986).

In addition, the innovation process requires time, whereas the return on investment is zero either in the short or medium term, and the profitability of investments appears only in the long term (Holmström, 1989). Investments in innovative projects have a small capacity to generate income in the short term, which pushes the lenders not to use this income to anticipate the future profitability of the project (Arrow, 1962). It is difficult for an external investor to select "good" projects. When it comes to long-term investments in an innovative project, this selection is easier when it comes to projects less risky and having short-term profitability (Leland \& Pyle, 1977). 
To summarize, in an innovative firm, profitability is naturally uncertain (Dubocage \& Rivaud-Danset, 2002), the return on investment is long term (Vaubourg, 2002), and the intangible elements take a dominant place in innovative assets. Moreover, Williamson (1988) asserted that the degree of asset specificity induces a high cost of the debt and concretely deters, either the banks to engage, either, the project bearers to ask the banks.

\section{Specific Financial Constraints Encountered by Innovative Companies}

The financial constraints encountered by the innovative companies have been a point of concern on several researches (Delbreil \& Laudy, 1987; Levratto, 1994; Samantha, 2009; Andrea, 2009; Bernard \& Sandra, 2003), these authors have tried to account for the four elements which can inhibit the development of SMEs, through consequences, and restructure the productive system by disrupting the SMEs in the choice of the financial structure conducive to sustainability, like: lack of funds, the debt overhang in the short term, the excessive weight of the business-to-business credit and the disparities in pricing of loanable resources.

The paper of Modigliani and Miller (1958) is considered as the gray area of the theory of the financial structure. These two authors have shown that, in perfect capital market and in the absence of the taxation, the financial structure does not affect the market value of the firm and there was no optimum structure and that funding therefore had no influence on the value of the company and on the weighted-average-cost of capital. The main interest of their reference is not so much its operational capacity but the fact that it compels any alternative theory to explain in a precise and rigorous manner, the choice of the determinants to take into consideration, in order to justify the non-neutrality of the financing structure (Hyafil, 1991). In fact, the approach of Modigliani and Miller (1958) is based on two proposals, as follows: the first is that the firm is indifferent to the choice of a mode of financing, with regard to the second proposal; it asserts that the cost of funds is a linear function of the growing debt/equity ratio. That said, this logic of Modigliani and Miller has not lasted long enough to be adapted to the problems of financing young innovative companies, more tests of these assumptions were allowed to highlight the influence of several determining factors, on the financial structure, leading to the rejection of the hypothesis of neutrality of the financing structure. By separating the investment decisions and financing (Gailly \& Laurent, 2010), we can apprehend neither the financial problems encountered by the innovative SMEs (high risk, absence of a history for the evaluation, and structural need in capital) nor the complexity of the contracts put in place in the framework of the financing granted (risk capital, business angels, public aid, etc.).

Given the high risk, the lack of guarantees and the strong informational opacity which characterize them, innovative SMEs can meet financial constraints. In fact, most researches that have been studying the topic of the innovation funding analyze the effect of the financial constraints on the innovative investment and evaluate the sensitivity of propensity to innovate or the expenditure of $R \& D$ by indicators reflecting the company richness (Gilchrist \& Himmelberg, 1995; Bond, Harhoff, \& Van Reenen, 2005).

Some authors affirm that the innovative activities are encountered by many difficulties of financing in a market of free competition. Apparently, this reflection took place with the papers of Nelson (1959) and those of Arrow (1962), although Schumpeter (1942) alluded to this idea in the book of Capitalism, Socialism and Democracy (1st edition ${ }^{1}$ ).

\footnotetext{
${ }^{1}$ See the Footnote 1, the chapter VIII of the 1st edition.
} 
The firms may encounter specific financial constraints (Berger \& Udell, 1998), when they are small, young companies or when they present important risk investment opportunities. According to the study of Planès, Bardos, Avouyi-Dovi, and Sevestre (2002), the innovative companies are not in such favorable situation, the third of firms that had an innovative project during 1994-1996 faced financial constraints which are reflected in the cost of access to the credit, and these constraints affect the firm financial autonomy which increases the risk of bankruptcy and the part of immaterial in the innovative investment.

\section{The Innovation and Financial Constraints: A Recent Review of Empirical Studies}

Savignac (2008) tried to evaluate simultaneously the probability to have innovative activities and the probability to face financial constraints. She also explained the endogenous nature of the financial constraint variable by linking it to the ex-ante financing structure of companies and economic performance. The empirical study conducted by Savignac showed that financial constraints have significantly reduced the probability of exercising an innovative activity. Similarly, Efthyvoulou and Vahter (2012) found that the lack of funding sources is a significant impediment to the performance of innovation in European countries, while Hottenrott and Peters (2012) indicated that the external financial constraints are more restrictive for R\&D and innovative activities.

An empirical study, conducted by Ayyagari, Demirguc-Kunt, and Maksimovic (2011) on 17,000 SMEs in 47 countries about innovation, found that companies which use external financing tend to be engaged in innovative activities. In another study on 16 European countries, Brown, Martinsson, and Petersen (2012) found strong evidence that the availability of finance promotes R\&D. In addition, through a study focused on 22 industries in 18 countries belonging to the OECD, Maskus, Neumann, and Seidel (2012) noted that bank credit and market capitalization have similar effects on the intensity of R\&D, and financial development and access to funding also are key reasons for companies in order to make the right choice between two countries when it comes to invest in R\&D.

De Mel, McKenzie, and Woodruff (2009), Ang (2010), and Silva and Carreira (2012) presented three different studies on the relationship between access to financial resources and innovation. These authors demonstrated that access to finance is positively correlated with the ability to innovate, however, this correlation may also reflect unmeasured productivity attributes of the company that are correlated with both its ability to innovate and its decision to receive a loan. Using the collected data in the Republic of Korea during the period of 1967-2005, Ang (2010) noted that there is a significant relationship between long-term production of knowledge and financial liberalization.

By analyzing the impact of the measure of self-evaluation of constraints on investment in R\&D, Silva and Carreira (2012) found that, when the endogeneity problem associated with this variable is taken into consideration, the financial constraints significantly mitigate the amount invested in R\&D. These authors showed that innovation in a broad sense is greatly hampered by financial constraints.

Nanda and Nicholas (2014) tried to trace the trajectory of innovation in different countries (based on the history of patents), and they found that a slump in the availability of external bank financing had, not only, an impact on the rate of innovation, but it had also changed the trajectory of innovation from experimental and radical innovations to incremental innovations, which means that disruption of the availability of capital has real effects in terms of innovation, noting that companies that were awarded quickly are the ones with high capital intensive. 


\section{Conclusion}

The question of financing the innovative companies made the subject of several studies. It is obvious that the financing of financial constraints is very important to finance companies engaged in the R\&D and in the innovation. Furthermore, the financial constraints of the innovative activities can be explained by several factors: the first factor may be caused by the company itself (its capacities can be insufficient to support financially the uncertainties on the profitability of innovative investment), the second is due to the risks of the lenders do not recover a part of their credit (Lhomme, 2001). Moreover, the difficulty to access to funds is probably the consequence of a brittle economic and financial health and the high default risk at the beginning. In need, the probability to meet financial constraints for the innovation can depend on the previous performances of the firm and on its structure of financing ex ante (Savignac, 2008).

In accordance with the literature, it seems that there is a relation between the structure of the capital and the results of innovation. However, Field (2003) showed that the 1930s was the most innovative decade of the 20th century. If finance is so central to innovation, how can it be reconciled that innovation progressed so well in a period that experienced one of the largest shocks to the banking system, in addition to disrupting the public debt and equity markets (Kerr \& Nanda, 2014)? Despite existing financial constraints, the investment in the innovation is the most crucial one for the economic development. For this reason, it needs an effective evaluation in order to contribute positively to the economic performance.

\section{References}

Aboody, D., \& Lev, B. (2000). Information asymmetry, R\&D, and insider gains. Journal of Finance, 55(6), 2747-2766.

Akerlof, G. A. (1970). The market for "lemons": Quality uncertainty and the market mechanism. Quarterly Journal of Economics, 84(3), 488-500.

Alter, N. (1999). La gestion du désordre en entreprise. Paris, L'Harmattan.

Andrea, M. (2009). Risk capital and innovation: Literature review part b “corporate venture capital”. Finnov Discussion Paper Work Package 3.

Ang, J. B. (2010). Research, technological change and financial liberalization in South Korea. Journal of Macroeconomics, 32(1), 457-468.

Arrow, K. (1962). Economic welfare and the allocation of resources for invention. In R. Nelson (Ed.), The rate and direction of inventive activity: Economic and social factors (pp. 609-626). Princeton University Press.

Ayyagari, M., Demirguc-Kunt, A., \& Maksimovic, V. (2011). Small vs. young firms across the world - Contribution to employment, job creation, and growth. Policy Research Working Paper 5631, The World Bank Development Research Group.

Barbe, D., \& Stephany, E. (2003). Le financement de l'innovation. Editions E-theque, pp. 1-25.

Belze, L., \& Gauthier, O. (2000). Innovation et croissance économique: Rôle et enjeux du financement des PME. Revue internationale P.M.E.: Économie et gestion de la petite et moyenne entreprise, 13(1), 65-86.

Berger, A., \& Udell, G. (1998). The economics of small business finance: The roles of private equity and debt markets in the financial growth cycle. Journal of Banking \& Finance, 22(6-8), 613-673.

Bernard, G., \& Sandra, M. (2003). Le capital à risque et les jeunes entreprises innovantes: Problématique et enjeux. Revue internationale P.M.E.: Économie et Gestion de la petite et moyenne entreprise, 16(3-4), 53-73.

Bernier, M. (2014). L'innovation dans les entreprises du Québec et du Canada. Institut de la statistique du Québec, March 2014, pp. 1-2.

Bhattacharya, S., \& Ritter, J. R. (1983). Innovation and communication: Signalling with partial disclosure. Review of Economic Studies, 50(2), 331-346.

Bhojraj, S., \& Lee, C. M. C. (2002). Who is my peer? A valuation-based approach to the selection of comparable firms. Journal of Accounting Research, 40(2), 407-439. 
Birraux, C., \& Le Deaut, Y. (2012). L'innovation à l'épreuve des peurs et des risques, rapport de l'Office parlementaire d'évaluation des choix scientifiques et technologiques. Retrieved from http://www.senat.fr/rap/r11-286-1/r11-286-111.html

Boly, V., Renaud, J., Lopez, M., \& Guidat, C. (1998). L'incertitude dans le contexte des projets innovants en PME: Définition, limite de la gestion de projet, première approche méthodologique. International Congress of SMEs, Metz, France.

Bond, S., Harhoff, D., \& Van Reenen, J. (2005). Investment, R\&D and financial constraints in Britain and Germany. Annales d'Économie et de Statistique, 79/80, 433-460.

Brown, J. R., Martinsson, G., \& Petersen, B. C. (2012). Do financing constraints matter for R\&D? European Economic Review, 56(8), 1512-1529.

Carpentier, C., \& Suret, M. (2000). L’évaluation des sociétés fermées: Pratiques et théories. Gestion, 25(3), 71-77.

Darby, M. R., Liu, Q., \& Zucker, L. G. (1999). Stakes and stars: The effect of intellectual human capital on the level and variability of high-tech firms' market values. Market Value, NBER Working Paper No. 7201.

David, A. (1988). Négociation et coopération pour le développement des produits nouveaux chez un grand constructeur automobile - Analyse critique et rôle des outils d'aide à la décision (Doctoral thesis, University of Paris-Dauphine).

David, A. (1996). Structure et dynamique des innovations managériales. Cinquième Conférence de l'AIMS Lille, Centre de Gestion Scientifique $N^{\circ} 12$, May 13, 14 et 15, pp. 2-3.

De Mel, S., McKenzie, D., \& Woodruff, C. (2009). Innovative firms or innovative owners? Determinants of innovation in micro, small, and medium enterprises. Policy Research Working Paper No. 4934, World Bank.

Delaunay, Q. (1995). Histoire de la machine à laver. Un objet technique dans la société française, préface de François Caron, Presses universitaires de Rennes, 1994. L'Homme et la société, 115(1), 136-137.

Delbreil, M., \& Laudy, J. (1987). Le financement des PME. Numéro spécial des Cahiers Économiques et Monétaires, Banque de France.

Deng, Z., Lev, B., \& Narin, F. (1999). Science and technology as predictors of stock performance. Financial Analysts Journal, 55(3), 20-32.

Denis, R. (2011). Innovation ouverte, capacités et innovations organisationnelles. Examen de la documentation 2003-2010. HEC. Montréal Cahier de recherche $\mathrm{N}^{\circ}$ 2011-March 02, pp. 4-7.

Depret, M., \& Hamdouch, A. (2008). La dynamique d'émergence et de développement des clusters et réseaux d'innovation dans les nouvelles technologies et les nouveaux services liés à l'environnement. De Boeck Supérieur Innovations, 2009/1 n² 29, pp. 127-147.

Dewar, R. D., \& Dutton, J. E. (1986). The adoption of radical and incremental innovations: An empirical analysis. Management Science, 32(11), 1422-1433.

Dosi, G. (1988). The nature of the innovative process. In G. Dosi, C. Freeman, R. Nelson, G. Silverberg, \& L. Soete (Eds.), Technical change and economic theory (pp. 221-238). Londres: Pinter Publishers LTD.

Drazin, R., \& Schoonhoven, C. B. (1996). Community, population, and organization effects on innovation: A multilevel perspective. Academy of Management Journal, 39(5), 1065-1083.

Dubocage, E., \& Rivaud-Danset, D. (2002). L’organisation des échanges sur le marché du capital-risque. Revue d'économie industrielle, 101(1), 31-46.

Efthyvoulou, G., \& Vahter, P. (2012). Financial constraints and innovation performance: Are all firms similar? University of Birmingham, 2012030, pp. 1-23.

Field, A. J. (2003). The most technologically progressive decade of the century. American Economic Review, 93(4), $1399-1413$.

Freel, M. S., \& Robson, P. J. A. (2004). Small firm innovation, growth and performance: Evidence from Scotland and Northern England. International Small Business Journal, 22(6), 561-575.

Gailly, B., \& Laurent, B. (2010). L'innovation: Un concept innovant. Revue Athena, Avril 2010, pp. 10-11.

Garcia, R., \& Calantone, R. (2002). A critical look at technological innovation typology and innovativeness terminology: A literature review. Journal of product Innovation Management, 19(2), 110-132.

Gilchrist, S., \& Himmelberg, C. P. (1995). Evidence on the role of cash flow for investment. Journal of Monetary Economics, 36(3), 541-572.

Hall, B. H., \& Lerner, J. (2009). The financing of R\&D and innovation. NBER Working Paper No. 15325, pp. 3-16.

Hall, B. H., Griliches, Z., \& Hausman, J. A. (1986). Patents and R\&D: Is there a lag? International Economic Review, 27(2), 265-284. 
Hamouti, R., \& Robert, F. (2012). Stratégie singulière, stratégie de coopération verticale ou stratégie de coopétition: Quelle est la meilleure stratégie pour l'innovation produit? Numéro spécial SSI - Revue Innovations - Cahiers d'Economie et de Management de l'Innovation.

Hoffman, K., Parejo, M., Bessant, J., \& Perren, L. (1998). Small firms, R\&D, technology and innovation in the UK: A literature review. Technovation, 18(1), 39-55.

Holmström, B. R. (1989). Agency costs and innovation. Journal of Economic Behavior and Organization, 12, 305-327.

Hottenrott, H., \& Peters, B. (2012). Innovative capability and financing constraints for innovation: More money, more innovation? Review of Economics and Statistics, 94(4), 1126-1142.

Hyafil, A. (1991). Décisions stratégiques et valeur de la firme. Revue française de gestion, 82, 45-57.

Kerr, W. R., \& Nanda, R. (2014). Financing innovation. Harvard Business School Working Paper 15-034, pp. 1-15.

Knight, F. (1921). Risk, uncertainty and profit. Reprints of economic classics Augustus M. Kelley, Bookseller, New Work, p. 233.

Lachmann, J. (1993). Le financement des stratégies d'innovation. Economica.

Leland, H. E., \& Pyle, D. H. (1977). Informational asymmetries, financial structure, and financial intermediation. The Journal of Finance, 32(2), 371-387.

Levin, R. C., Klevorick, A. K., Nelson, R. R., Winter, S. G., Gilbert, R., \& Griliches, Z. (1987). Appropriating the returns from industrial research and development. Brookings Papers on Economic Activity, 3, 783-831.

Levratto, N. (1994). Le financement de l'innovation dans les PMI. Revue d'économie industrielle, 67(1), 191-210.

Lhomme, Y. (2001). Le financement de l'innovation technologique dans l'industrie. Le 4-Pages, SESSI, n 156. pp. 1-4.

Loilier, A., \& Tellier, A. (1999). Gestion de l'innovation: Décider mettre en œuvre diffuser. Editions EMS, 214 pages.

Maskus, K. E., Neumann, R., \& Seidel, T. (2012). How national and international financial development affect industrial R\&D. European Economic Review, 56, 72-83.

Modigliani, F., \& Miller, M. H. (1958). The cost of capital, corporation finance, and the theory of investment. American Economic Review, 48(3), 261-297.

Nanda, R., \& Nicholas, T. (2014). Did bank distress stifle innovation during the Great Depression? Journal of Financial Economics, 114(2), 273-292.

Nelson, R. R. (1959). The simple economics of basic scientific research. Journal of Political Economy, 67(3), 297-306.

O’Regan, N., \& Ghobadian, A. (2005). Innovation in SMEs: The impact of strategic orientation and environmental perceptions. International Journal of Productivity and Performance Management, 54(1/2), 81-97.

Organization for Economic Cooperation and Development [OECD]. (2005). Principes directeurs pour le recueil et l'interprétation des données sur l'innovation. Manuel d'OSLO. 3ème édition.

Orlikowski, W. J., \& Baroudi, J. J. (1991). Studying information technology in organizations: Research approaches and assumptions. Information Systems Research, 2(1), 1-8.

Pairault, T. (1993). Banques et PME et financement tontinier. In B. Ponson, \& J. L. Schaan (Eds.), L'esprit d'entreprise: Aspects managériaux dans le monde francophone (pp. 427-446). Ottawa: John Libbey Eurotext.

Planès, B., Bardos, M., Avouyi-Dovi, S., \& Sevestre, P. (2002). Financement des entreprises industrielles innovantes: Contraintes financières et risque. Bulletin de la Banque de France, No. 98, Banque de France.

Roberts, J., \& Milgrom, P. (1997). Economie, organisation et management. De Boeck Université.

Samantha, S. (2009). Risk capital and innovation: Literature review - part a “venture capital”. FINNOV Discussion Paper Work Package 3.

Savignac, F. (2008). Impact of financial constraints on innovation: What can be learned from a direct measure. Economics of Innovation and New Technology, 17(6), 553-569.

Scherer, F. M. (1998). The size distribution of profits from innovation. Annales d'Economie et de Statistique, 49/50, 495-516.

Schumpeter, J. (1934). The theory of economic development. Cambridge, Mass.: Harvard University Press.

Schumpeter, J. (1942). Capitalism, socialism and democracy. New York, NY: Harper.

Schumpeter, J. (1999). Théorie de l'évolution économique: Recherches sur le profit, le crédit, l'intérêt et le cycle de la conjoncture. Edition Dalloz.

Sfez, L. (1973). Critique de la décision. Presses de la fondation nationale des sciences politiques. 4ème revised and expanded edition on 1992.

Silva, F., \& Carreira, C. (2012). Do financial constraints threat the innovation process? Evidence from Portuguese firms. Economics of Innovation and New Technology, 21(8), 701-736. 
St-Pierre, J., \& Beaudoin, R. (1999). Financement de l'innovation dans les PME: Une recension récente de la littérature. Institut de recherche sur les PME- université du Québec à trois rivières, Rapport de veille, Canada.

Van de Ven, A., Polley, D., Garud, R., \& Venkataraman, S. (1999). The innovation journey. New York, NY: Oxford University Press.

Vaubourg, A. (2002). Essais sur l'architecture des systèmes financiers: Analyse théorique et empirique du partage entre banque et marché (Thèse, Université Orléans).

Villemeur, A. (2010). Risque et innovation. Revue Risques n 81/2010, pp. 1-2.

Weil, B. (1996). Gestion des savoirs et organisation de la conception des produits industriels (Doctoral thesis, Ecole Nationale Supérieure des Mines of Paris).

Williamson, O. E. (1988). Corporate finance and corporate governance. Journal of Finance, 43(3), 567-591. 